\title{
INDEBTEDNESS OF FINANCIALLY VULNERABLE HOUSEHOLDS: WHAT DO SOCIAL WORKERS DO?
}

\section{Lambert Engelbrecht}

\section{INTRODUCTION}

Household debt in South Africa has grown significantly relative to income over the past twenty years under the guise of financial liberalisation (FinMark Trust, 2007). Currently households spend approximately 60c to 70c of every rand of their income on repayment of debt (Gous, 2008; Van Rooyen, 2008a). During the past decade the disposable income, financial assets and net prosperity of households have therefore not accrued to the same extent as their debt obligations. For this reason households' savings are urgently needed to contribute to a lessening of the country's current account deficit in order to sustain economic growth and job creation (Van Tonder, 2008). On the macro level, economic growth and job creation form part of the ideal underpinning the social development philosophy in South Africa. This ideal is to combine social welfare assistance with developmental strategies, thereby promoting both economic and social development in order to strengthen people's capacity to enhance their social and economic inclusion and alleviate poverty (Patel, 2005:118). Social work, as a profession within the social development paradigm, is primarily focused on the poorest of the poor households (Department of Social Development, 2006). In the context of a relative poverty line, set in relation to changing standards of living (Statistics South Africa, 2007), a poor household is to be understood when the household's condition of poverty endures over a period of time, when the household has an inability or lack of opportunity to improve its circumstances over time, or to sustain itself through difficult times (Aliber, 2001:2). Research (Collins, 2007; Rand, 2004) has shown that poor households have the highest debt to income ratio. For this reason social work intervention focusing on household debt is also essential on the micro level within the social development paradigm in order to reduce households' financial vulnerability (Engelbrecht, 2008a).

Research into the debt levels of social work service users and specific social work intervention in this regard, however, is non-existent in South Africa. To shed more light on this issue this article reports on research grappling with the question of what social workers, working within a social development paradigm, do to assist clients who are caught in a debt trap.

\section{BACKGROUND TO THE RESEARCH}

As background to and point of departure of the research question as set out above, the context of the indebtedness of poor households in South Africa, will be explored.

\section{Impact of the South African economic situation on the debt of the poor}

In South Africa high inflation, weakening of the rand and increased interest rates, implying that expenditure exceeds production, arise partly from the global economic meltdown, but also from government initiatives to appropriate ever more of the state revenue for social assistance to the poor rather than improving infrastructure and production skills (Buys, 2008). For example, over the past few years lower-income groups have received strong support through tax incentives and social grants. About $26 \%$ of South Africans already receive social welfare grants, among the highest percentages of grants in the world (Van Tonder, 2008). As a result the disposable income of welfare recipients has risen considerably, which also means that they simply become more creditworthy to incur more debt (Gous, 2008). A 1\% increase in social welfare grants 
could, for example, cause a rise of $0,6 \%$ in household expenditure (Van Tonder, 2008). Consumers earning less than R3 500 per month, most of whom are welfare recipients, represent 23,5\% of active consumers of credit in South Africa (Watson, 2008). More than half of these households are already in arrears with debt repayments. In view of South Africa's current economic instability, it is therefore of the utmost importance that debt be managed effectively, not only on the macro level, but also on the micro level (Cillie, 2008).

\section{The role of retail banks in debt of the poor}

It seems, however, that banks are relatively unsuccessful in contributing to effective money management by people in South Africa (Schoombee, 2000). Half of the South African population, for example, do not make use of banking services (Harris, 2008). The use of banking services by very low-income households is estimated at only 22\% (Porteous, 2003). Research (FinMark Trust, 2007) also indicates that poor households mostly do not use their savings accounts, and withdraw wages or grants in total, as they are deposited (Van Zyl, 2008a). These statistics on the "un-banked" or the "under-banked" (Sandlant, Harris \& Barker, 2005) confirm research findings on the direct correlation between financial illiteracy and poverty in terms of financial exclusion (Bell \& Lerman, 2005; Jacob, Hudson \& Bush, 2000; Sandlant et al., 2005).

Several reasons explain the under-utilisation of banks in South Africa. During apartheid, for example, banking services were not focused on black South Africans (Foyer, 2000), resulting in a distrust and lack of knowledge of banks on the part of many poor people. A South African Reserve Bank and National Treasury Report, furthermore, points out that South African bank charges are among the highest in the world, which contributes to the unwillingness of the poor to make use of banking services (Du Preez \& Clayton, 2004).

The government is currently applying pressure on banks to enter the poor segment of the South African population. Most banks are, however, still unable or hesitant to offer extensive services to the poor on account of the risks involved, transaction size and operational costs. This situation, of course, is not unique to South Africa, because generally speaking, unless there is profit to be made from the poor, they will not be served (Schoombee, 2000). The focus of banking initiatives is also largely on loans and not on savings (Fair Share, 2001). This scenario led Tito Mboweni, the Reserve Bank governor, to express his concern about the spiralling household debt of South Africans (Loxton, 2004). In response the National Credit Act No. 34 of 2005 (RSA, 2005) and National Credit Regulations (RSA, 2006) were promulgated.

\section{The National Credit Act (Act No. 34 of 2005) and National Credit Regulations (2006) as the government's response to household debt}

The Department of Trade and Industry in South Africa is responsible for overseeing the credit market to promote a stable, efficient and competitive credit market in which consumers' rights are adequately protected, and in which access to finance (i.e. credit) is improved, particularly for development purposes (RSA, 2004). With the introduction of the National Credit Act (RSA, 2005) and National Credit Regulations (RSA, 2006), the South African government is thus moving aggressively against predatory lending, consumer abuses and outdated and ineffective legislation on consumer credit. Suppliers of credit will be subsidising part of debt counselling. Debt counsellors will be acting as mediators between creditors and over-indebted consumers (Van Zyl, 2008b). Over-indebtedness is a key concept in the National Credit Act (RSA, 2005), as well as an international judicial concept which ultimately determines whether a consumer is creditworthy (Goodwin-Groen \& Kelly-Louw, 2006). The extent to which households will be 
able to make use of debt counsellors will, however, in future be determined by the context of indebtedness of the poor.

\section{Contextualisation of over-indebtedness of poor households}

Over-indebtedness is defined by the National Credit Act (RSA, 2005: section 79), in the light of the preponderance of information available at the time a determination is made, as the inability of the consumer to satisfy in a timely manner all the obligations under all the credit agreements to which the consumer is a party. Over-indebtedness thus implies using loans to pay off other loans, and allocating more than fifty percent of monthly net income to loan repayments (Mashigo, 2006). According to this definition, over-indebtedness of South Africans has increased since 1995, especially amongst the poorest households, who are the most vulnerable to becoming permanently indebted (Micro-Finance Regulatory Council, 2003). This context suggests, moreover, that welfare grant recipients have the highest debt service to income ratio of all the livelihood profiles, because their financial management consists of making money last until the next grant payment (Collins, 2007; Rand, 2004) and they are borrowing against their state grants (Nagdee, 2004). Grant recipients form part of the poorest $40 \%$ of households in South Africa, earning less than $7 \%$ of the country's total household income (Ueckermann, 2008).

Poverty in South Africa must, however, be viewed within a wider context than solely financial income and cannot be examined realistically without a consideration of household assets. For example, the Development Indicators of 2008 (The Presidency Republic of South Africa, 2008) reveal that $82,2 \%$ of households in South Africa occupy formal dwellings or traditional structures. In addition, a total of $90 \%$ of the population have use of cell phones (Eybers, 2008). These examples imply features of money in circulation, but as a result of its informal nature, it is contentious to quantify and reflect statistically the money in circulation. The debt behaviour of poor households should therefore be examined.

\section{Debt behaviour of poor households}

The fact that most South Africans are trapped in a culture of debt simply means that a pattern of debt behaviour is sustained (Cillie, 2008). A simplistic cause and effect analysis of the reasons for households' debt, however, would be unscholarly. A combination or non-hierarchical interplay of a complex set of interwoven hypothetical determinants giving rise to overindebtedness seems to be more to the point for the majority of South African households. These determinants could be integrated, synthesised and explained on the basis of expositions by Nash, Jenkinson, Vayro and Sandlant (2005) and INSOL International (2001), in terms of a metaphorical "Bermuda debt triangle" absorbing household incomes. One determinant, or angle, of the triangle consists of survival debts which are unavoidable and out of control, arising from the lack of income and basic commodities for survival. The second determinant of the triangle deals with cognitive debt, which can largely be ascribed to a lack of knowledge, or financial illiteracy. The third determinant can be typified as affective or emotional debt, arising from, for example, individual disposition or peer pressure. The following figure is a graphic elucidation of the Bermuda debt triangle. 


\section{THE BERMUDA DEBT TRIANGLE}

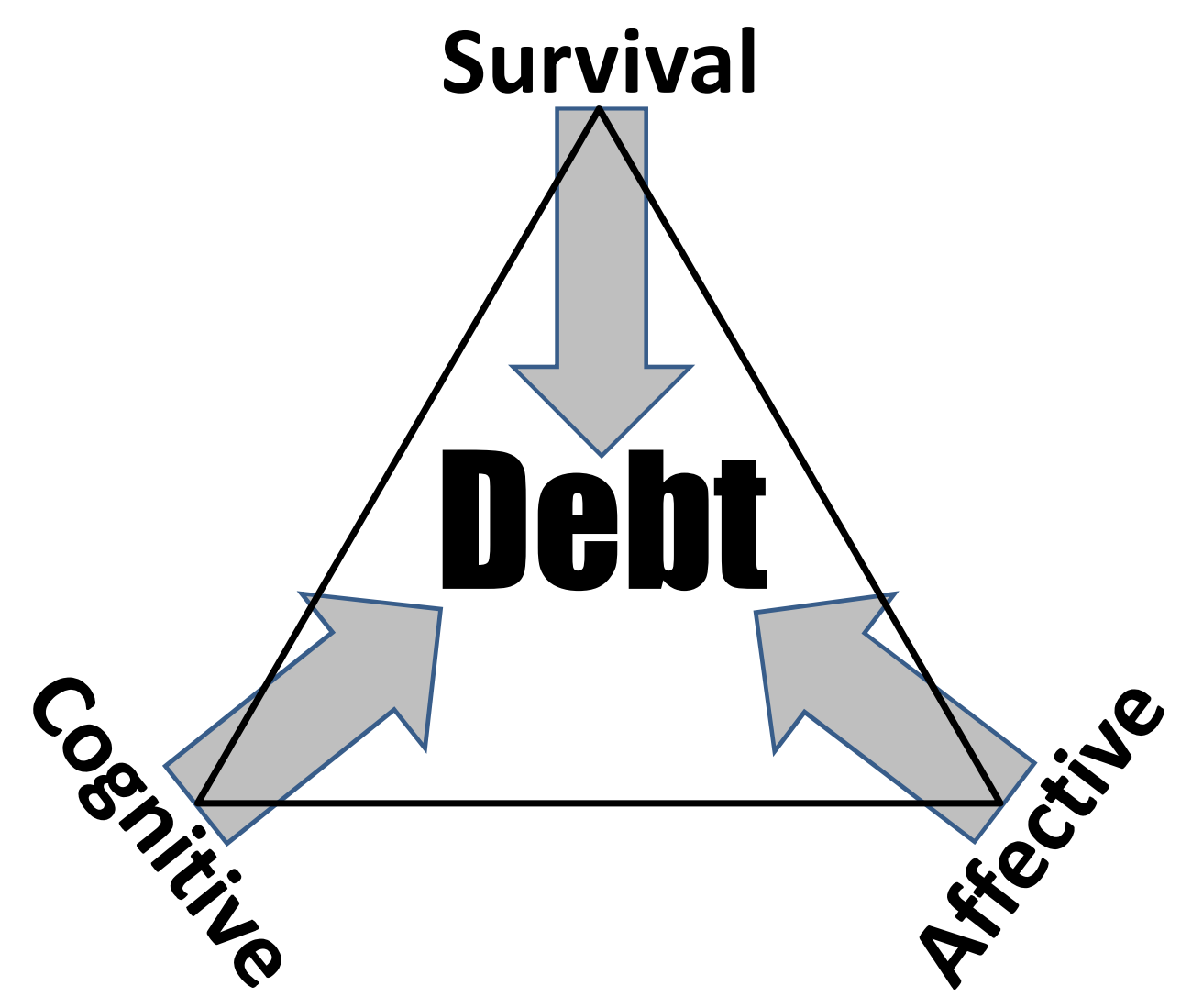

(Nash, Jenkinson, Vayro \& Sandlant, 2005; INSOL International, 2001)

Unemployment and abject poverty in general are undoubtedly the greatest cause of survival debt, as postulated by such researchers as Schoombee (2000) and Mashigo (2006). What is questionable, however, is the ability of research respondents who are in debt themselves to report on their cognitive and affective debt. The Bermuda debt triangle is thus operationalised when researchers report that "Everybody in the focus group bought on credit at their local 'spaza', even though they paid double the price and/or interest on goods purchased" (Nagdee, 2004:76). The fact that everybody buys at the "spaza" (informal shop) could indicate affective debt as a result of peer pressure. Paying double the price and/or interest could indicate cognitive debt resulting from financial illiteracy. Shopping at the "spaza" could well mean that it is the only place where respondents qualify informally for credit buying of basic foodstuffs for survival - thus considered as survival debt. To place these determinants of the Bermuda debt triangle into a specific hierarchy would therefore be plain speculation.

One aspect which cannot be ignored, and which further complicates the Bermuda debt triangle in South Africa, is that, according to Schoombee (2000), the excitement and jubilation of the newly experienced freedom following the first democratic election in South Africa in 1994 created the expectation in many poor people's minds that luxury consumer goods previously thought to be within reach of only the oppressors could also be acquired by poor households. This euphoria was further stimulated by the political transition and economic transformation in South Africa which resulted in an increase in the ability of a larger proportion of households to borrow (Hurwitz \& Luiz, 2007). Especially deceptive advertisements like "We can loan you 
enough money to get you completely out of debt" (Goodwin-Groen \& Kelly-Louw, 2006:47) contributed to the vulnerability of the poor. As a consequence credit-active consumers in South Africa currently hold 3,02\% accounts per consumer, while 37,7\% of consumers with credit accounts already have a bad record on one or more of their accounts (Gous, 2008).

It is clear therefore that more accessible loans, especially as part of initiatives to start up small businesses, are rather used for consumption purposes. Poor households are currently spending, for example, between $50 \%$ and $80 \%$ of their income on food (Muller, 2008). Lower-income groups experience greater pressure from inflation than do higher-income groups, as food which has risen sharply in price recently, accounts for a much greater part of their budget (Van Rooyen, 2008a). This explains why most of the loans to poor households in South Africa are spent on basic necessities (Black Sash, 2000). Determining what poor people consider to be basic necessities, however, is context bound. A bank for low-income groups claims, for example, that $55 \%$ of their loan clients possess a credit card of a well-known retail group in South Africa and $46 \%$ of their clients have accounts at furniture stores (Duvenhage, 2008a).

The debt behaviour of the poor and especially of welfare grant recipients is further characterised by informal borrowing from relatives, neighbours, friends, credit at the local store and credit from informal sellers of goods (Collins, 2007). Whenever there is a need for money or basic necessities, most people in these communities turn to those closest for help, who expect them to return the favour some time in the future (Mashigo, 2006). The result is that people sometimes keep one another in the poverty trap, as the focus is on borrowing and not saving (Roy Morgan Research, 2003). Giving to others could thus be defined as loaning, as an expectation is created of "I give today, but tomorrow I must receive".

However, the biggest proportion of low-income borrowers in South Africa makes use of the services of micro-lenders, as their income is too low to meet basic expenses for survival (Schoombee, 2000). Micro-finance is generally considered and promoted as part of poverty alleviation and as a job-creation strategy (Gelinas, 1998). For this reason the South African government has since the late 1990s cooperated actively to extend the micro-finance sector. This had the unintended consequence of the dependence of low-income households on formal micro-lenders and informal local money lenders for the provision of credit. The desired outcome of micro-finance for emerging business and job creation in South Africa was thus not achieved (Mashigo, 2006). The debt collection methods of some money-lenders are furthermore unorthodox and dubious, and are now adding to the vulnerability of low-income groups. Especially welfare grant recipients could be easy prey, as well as low-income workers with a regular source of income. The Micro-Finance Regulatory Council (1999) attempted to regulate and protect consumers, but it seems that this Council has so far been unable to educate consumers as intended.

\section{Savings by poor households}

It is evident from the preceding exposition that the culture of saving in South Africa is weak and is not being encouraged as rigorously as credit is sought. Change could only be effected through legislation, putting pressure on people to save (Mittner, 2008). South Africans are currently saving at a rate of only $14 \%$ and, according to Trevor Manuel, a former Minister of Finance, people will have to save more for the economic growth rate of the past few years to be continued. In this regard the South African Treasury is working on an extended campaign to motivate South Africans to save more (Van Rooyen, 2008b). Savings initiatives are considered an empowerment tool for the poor, but should be appropriate to the context of a specific 
income group (Collins, 2007) as illustrated by the Individual Development Accounts (IDA) in the United States (Sherraden \& Sherraden, 2004). IDAs are special savings accounts designed to assist low-income people on their path toward asset ownership through matched savings and financial education.

However, willingness to save has been positively correlated with education levels and more specifically financial literacy, which should be based on general theories of household savings behaviour (FinMark Trust, 2007). Examples of these theories of household savings behaviour are the following: neoclassical theories which assume that individuals are rational and forwardlooking and that savings reflect inter-temporal utility-maximising behaviour; psychological and sociological theories which emphasise inter alia the impact of motivation and aspiration; behavioural theories, which focus on behavioural incentives and constraints; and institutional theories, which highlight the role of institutional processes and mechanisms in a household's savings behaviour (FinMark Trust, 2007). These theories, however, all suggest that the poor can save.

In terms of the question as to whether the poor can save, Trevor Manuel (Manuel, 2004:6) declares: "(W)e have seen a proliferation of micro-loans to this segment. Repaying debt implies potential ability to save", a viewpoint echoed by several influential commentators (FinMark Trust, 2007; Human Sciences Research Council, 2002; Rand, 2004; Rutherford, 1999). Statistics South Africa also points out, for example, that the lower income groups can save up to $20 \%$ of their income (Van Rooyen, 2008b). It is therefore a myth that the lower-income groups cannot and will not save. Financial institutions thus need to design relevant and appropriate products for lower-income groups, which would enable them to save. A concrete example of savings by the poor is the use of a rotating credit scheme or informal savings organisation in the African community, which is known as a "stokvel" (Mashigo, 2006).

\section{Correlation between financial and human well-being}

Unfortunately, for the majority of people financial hardship is an overwhelming experience of feeling out of control, which could be extremely stressful. Feelings of helplessness, isolation, despair and depression are thus common and tend to lead to dysfunctional intra- and interpersonal relationships (Foyer, 2000; Nash et al., 2005). In this sense financial well-being, as described by Braunstein and Welch (2002) and Mavrinac and Ping (2004), is equivalent to human well-being, as both concepts constitute "a state of successful performance throughout the life course ... that results in productive activities" (Pollard \& Davidson, 2001:10). Financial literacy education should thus be facilitated as a poverty alleviation tool with the primary mission of promoting social change in order to enhance the well-being of financially vulnerable people (Engelbrecht, 2008b).

\section{Financial literacy education as a poverty-alleviation tool}

Goodwin-Groen and Kelly-Louw (2006) point out that debt counselling, as prescribed by the National Credit Act (RSA, 2005), is important, but preventing over-indebtedness is equally important. Therefore Goodwin-Groen and Kelly-Louw (2006) recommend public education campaigns to promote saving and financial literacy education as a way to prevent overindebtedness. The extent of people's indebtedness could be an indication of their financial literacy. However, financial literacy education to low-income communities is currently inadequate in spite of the obviously low level of financial literacy of poor households in South Africa (Piprek, Dlamini \& Coetzee, 2004). In this connection Engelbrecht (2008a; 2008b) 
comprehensively elucidates financial literacy education as a poverty alleviation tool within a developmental social work paradigm.

\section{RESEARCH METHODOLOGY}

The aim of this research was to gain an understanding of what social workers do regarding the indebtedness of their clients. To this end a research process consisting of the literature study and an empirical study was followed. This process requires an interchange between inductive and deductive logic and reasoning (Siepert, McMurty \& McClelland, 2005:232) in order to identify related aspects and ensure a coherent exposition. The financial business rubrics of relevant South African newspapers were particularly consulted to reflect cutting-edge data and expert views on the issues at hand. The goal of the research was further realised by a combined qualitative and quantitative research approach (Fouché \& Delport, 2005:79) and by employing a cross-sectional exploratory and descriptive design (Grinnell, Unrau \& Williams, 2005:16-18). Non-probability sampling (Schutt, 2005:164, 166) was utilised, because the idea was merely to obtain as much data on the research question as possible to develop an understanding. A purposive sample targeted a universe of 85 front-line social workers who are all attached to an NGO operating in three provinces in South Africa (Western Cape, Eastern Cape and Northern Cape), doing generalist social work according to an integrated service delivery model (Department of Social Development, 2006) within South Africa's social development paradigm. A structured self-administered questionnaire with open and close-ended questions to generate both qualitative and quantitative data was utilised as a data-collection method. Creswell's (1998) and Marshall and Rossman's (1999) processes for the analysis, interpretation and presentation of qualitative data were employed as guidelines to structure and to reflect the responses of social workers into meaningful themes (Delport \& Fouché 2005:354).

\section{FINDINGS}

The response rate from the social workers was relatively high, as 74 (87\%) of 85 questionnaires were completed and returned.

\section{Biographical details of respondents}

An analysis of the service area of the respondents indicates that $38(51 \%)$ of them work in an urban and urban-rural areas, while 36 (49\%) work only in a rural area. The respondents from these service areas therefore present a balance of both urban and rural conditions, although this research study was not aimed at an analysis of discrepancies in service areas. The respondents deliver social welfare services to 10951 households, which implies an average caseload of 148 households per social work respondent. The respondents' reflections on the total number of households, financially vulnerable households and over-indebted households in their caseloads are shown in the next figure. 
FIGURE 2

\section{OVER-INDEBTED, FINANCIALLY VULNERABLE AND TOTAL NUMBER OF HOUSEHOLDS IN RESPONDENTS' CASELOADS}

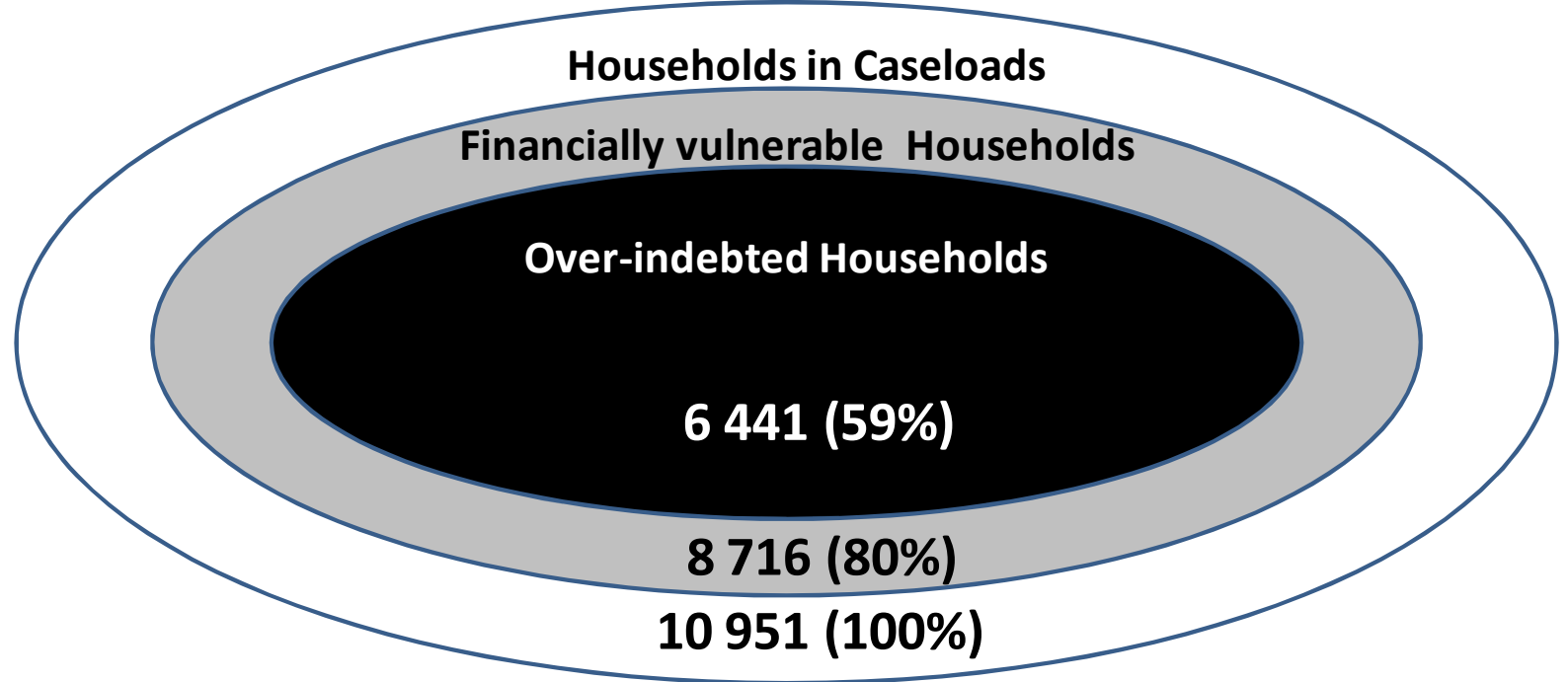

\section{Financial vulnerability of households}

Almost all of the households (8716 or 80\%) are considered financially vulnerable by respondents. The social work services of the NGO concerned are thus in line with the Integrated Service Delivery Model of the Department of Social Development in that the social workers focus on the "poorest and most vulnerable sectors of society" (Department of Social Development, 2006:2).

The main reason supplied by respondents for the financial vulnerability of households in their caseloads is unemployment, largely as a result of a scarcity of job opportunities, but also because of lack of skills. This concurs with Buys's (2008) view on the deficient skills levels of the people in South Africa. According to the respondents, a lack of skills contributes to jobs being only temporary or seasonal. This results in a considerable number of households being without any income for parts of the year. In addition, poor financial planning and misapplication of funds are considered a leading cause of financial vulnerability, especially in the absence of a culture of saving, as also found by Cillie (2008). Eybers (2008) points out that the misapplication of funds implies that poverty in South Africa should also be viewed in terms of households' assets, and that there is in fact money in circulation, albeit difficult to quantify because of the informal nature of such circulation.

Social problems such as substance abuse and health issues such as HIV and Aids further contribute to financial vulnerability. Other determinants pointed out by respondents include single-parent families, too large families, unplanned pregnancies and elderly people dependent on state pensions. This profile of financial vulnerability corresponds with local and international research (Nash et al., 2005; Piprek, et al., 2004; Rand, 2004; Sandlant et al., $2005)$ indicating that the determinants of financial vulnerability are universal.

\section{Over-indebtedness of households}

According to the respondents, altogether 6441 (59\%) of households in their caseloads are overindebted. This agrees with findings by Watson (2008) that more than half of the poor households in South Africa are in arrears with debt repayments. Respondents indicate that they are especially conscious of their clients' over-indebtedness when they deal with statutory 
162

assessments, for example, foster care applications, children's court procedures or rehabilitation reports, when an exposition of households' finances is a statutory requirement. The assessment of households' financial positions is traditionally an essential part of social work intervention, as described in the first contributions of social work pioneers such as Mary Richmond (1917:380).

According to respondents, households mostly require direct material assistance with their overindebtedness, as illustrated by the following remarks:

"The clients will inform the social worker about their debt...even show the account slips.”

"Most families are honest about debt, as they want assistance from social workers with, for example, a food parcel, school uniforms for children, help with housing, etc."

It seems therefore that survival debt is the main motivation for households to accept social work intervention. Cognitive and affective debt is not easily made known, as illustrated by the fact that only an insignificant number of respondents indicate that households' indebtedness in this respect is reported by friends, family members or community members.

\section{Debt behaviour of vulnerable households}

The debt behaviour of vulnerable households is in correlation with the determinants of the "Bermuda debt triangle" (Nash et al., 2005; INSOL International, 2001). An example of a comment on survival debt is the following:

"My clients even have to borrow the basic necessities."

Respondents also perceive that clients are uninformed and lack financial planning skills, which relates to cognitive debt:

"My clients manage to obtain accounts at various stores which encourage them to spend, but do not explain the fine print of how a credit account works.”

"In this area, borrowing is part of the social culture ... everybody borrows and is in a debt trap ... the perception is that saving is done by people with lots of money, who have everything their hearts desire."

The desire to own luxuries, as illustrated in advertisement campaigns and described by Goodwin-Groen and Kelly-Louw (2006: 47), is given by respondents as another reason for their clients' over-indebtedness, and corresponds with affective debt:

"Clients also want to spoil themselves sometimes..."

The nature of the above-mentioned debt behaviour means, according to the respondents, that households in their caseloads are so caught up in a debt trap that the interwovenness of the various creditors is difficult to untangle. Respondents, echoing findings by Cillie (2008), Collins (2007), Gous (2008) and Mashigo (2006), indicated that most households have at least three creditors, borrow to repay other loans, secure informal loans which do not have to be given account of, and reside in a culture where borrowing and indebtedness are the norm.

\section{To whom are the households indebted?}

Most respondents, namely 49 (66\%), reported that households in their caseloads owe the most money to furniture stores, mostly for luxury or brand name articles and electrical appliances. This differs from other research findings (Black Sash, 2000) that poor people in South Africa are most indebted just trying to buy basic necessities, but correponds with the postulation by 
Duvenhage (2008b) that a considerable percentage of low-income groups also hold accounts for furniture and clothes.

The findings of Gelinas (1998) that a large number of low-income borrowers owe money to micro-lenders are also supported by respondents. Micro-loans are used to obtain money to pay other debts. Considerable debt is also incurred at informal shops, as they are easily accessible and no creditworthiness needs to be proved. Friends, acquaintances and employers are further sources of credit. Other institutions owed considerable amounts of money are municipalities, schools, banks, landlords and second-hand shops, correlating with research by Collins (2007), FinMark Trust (2007) and Mashigo (2006). It seems therefore that sources where debt is incurred are determined by the environment, accessibility and availability.

\section{The impact of households' over-indebtedness on their social functioning}

According to respondents, the stress of households' over-indebtedness, contributes greatly to family violence, substance abuse and child abuse. A lack of food, malnourishment and undernourishment are obvious consequences. Other social problems such as theft, prostitution and begging could also be directly attributed to over-indebtedness, as described by Nagdee (2004) and Nash et al. (2005), thus confirming the correlation between financial and human wellbeing, as expounded by Braunstein and Welch (2002), Mavrinac and Ping (2004), and Pollard and Davidson (2001:10).

\section{Social work intervention in respect of over-indebtedness}

The next figure illustrates the social work respondents' reflections on their intervention in respect of their clients' over-indebtedness.

FIGURE 3

\section{SOCIAL WORK INTERVENTION IN RESPECT OF OVER-INDEBTEDNESS}

\section{SOCIAL WORK INTERVENTION}

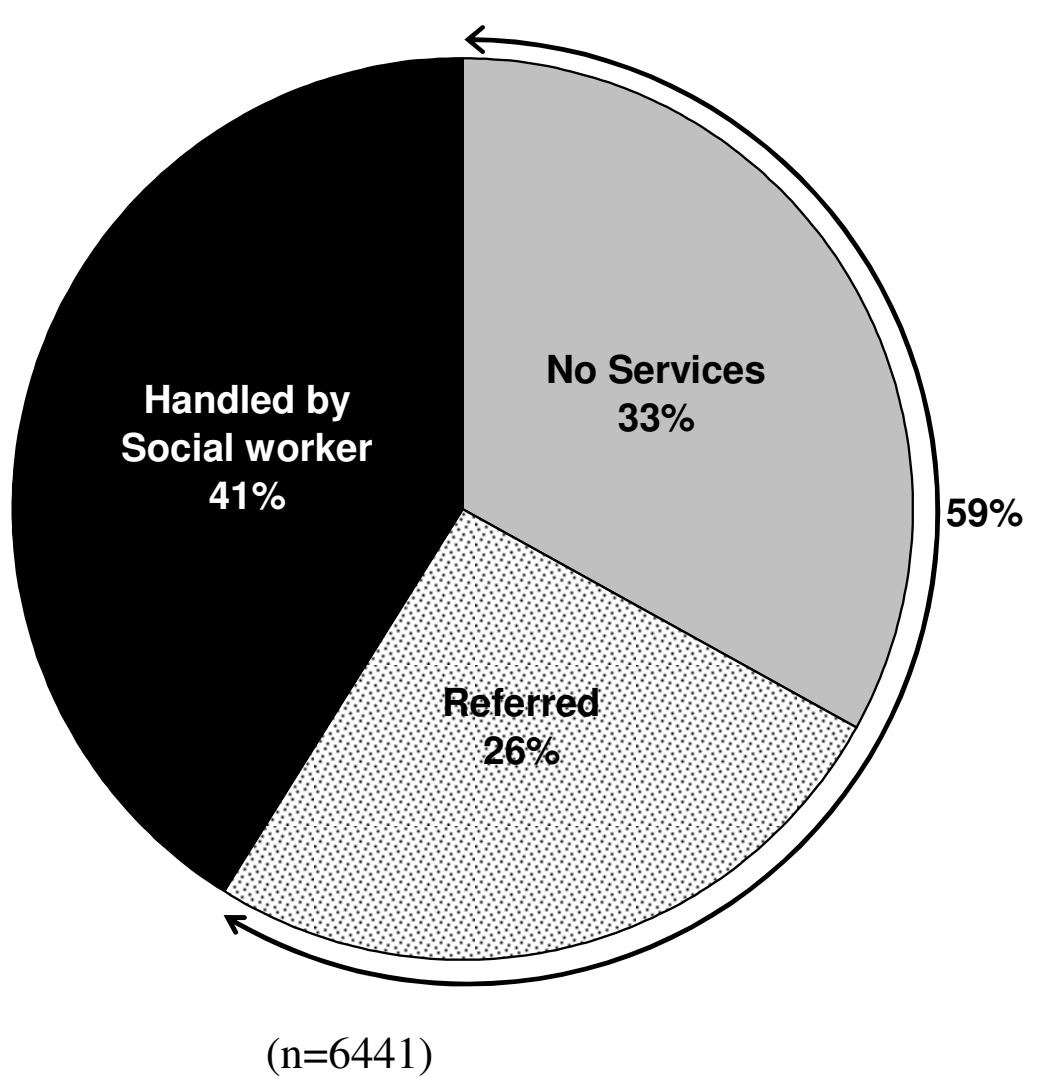

Social Work/Maatskaplike Werk 2009:45(2) 
Out of the 6441 households identified by respondents as over-indebted, 1674 (26\%) were referred by the respondents to other sources. Most respondents refer their over-indebted clients to the Department of Social Development to apply for welfare grants, if they are not already recipients of applicable grants. A few respondents refer clients to legal aid clinics to obtain legal aid, but this service is not freely available. Referrals to financial institutions are done only in exceptional circumstances, as indicated by only two respondents. Not one respondent mentioned referral for debt counselling, as prescribed by the National Credit Act (RSA, 2005).

A collation of the total responses of the social workers shows that 2641 (41\%) over-indebted households $(n=6441)$ are handled by them. These responses indicate that most social workers try to teach these clients some or other form of budgeting skills, and then mainly on an individual basis. Few or no other sources are utilised or facilitated. Furthermore, merely temporary material assistance in the form of food parcels or soup kitchens is offered. The repertoire of the social workers' intervention activities in the matter of clients' overindebtedness seems to be confined to merely teaching budgeting skills and does not focus on the whole spectrum of financial literacy education which could be appropriate for the households concerned, as suggested by a host of international and local institutions and authors (Braunstein \& Welch, 2002; FinMark Trust, 2007; Mavrinac \& Ping, 2004; Nash et al., 2005; Piprek, et al. 2004; Rand, 2004; Sandlant et al., 2005).

The respondents reported that no services in the matter of indebtedness are delivered to 2126 $(33 \%)$ of the households identified by them as over-indebted $(n=6441)$. These households which receive no social work intervention pertaining to their indebtedness, and those that are referred, therefore constitute more than half of the total number of over-indebted households involved in this research, namely 3800 (59\%). The main reason given by respondents for this situation is that the identified over-indebted households show resistance to social work intervention, other than direct material assistance:

"These clients expect only material assistance and do not accept their own responsibility."

"As everybody in the community is in debt, clients do not consider their overindebtedness to be exceptional - it is part of life."

This resistance of households also requires scholarly analysis within the context of the various theories of household debt behaviour (FinMark Trust, 2007) and should be integrated with theories of human behaviour peculiar to social work in order to effect social change (Hare 2004:414). Social change is similarly reflected in the rationale of financial literacy education, which is to empower people to exercise informed financial choices (Mavrinac \& Ping, 2004).

Respondents furthermore experience a total lack of resources in the matter of intervention regarding their clients' indebtedness and mention other priorities in their caseloads:

\section{"I do not have enough time to help people in debt."}

It seems that the respondents' lack of time could be blamed largely on their huge caseloads, but the services of volunteers who could make a great contribution to intervention are, according to the responses, not optimally utilised. Respondents also do not refer to their role as facilitators (Engelbrecht, 2008b) in intervention with over-indebted households, and they seem to assume that their involvement with the over-indebted households should only be on the level of direct service delivery and specifically in terms of case work intervention. The conclusion by 
Engelbrecht (2008c: 172) that "it seems that social workers in general are so caught up with trying to deal with clients' presenting problems that there has been little conscious effort to develop their economic literacy, except as a by-product of 'normal' casework intervention" is thus also confirmed by this study.

Some respondents justify their lack of involvement in intervention to over-indebted households by arguing that this type of service delivery does not pertain to a social worker:

"I was not trained to give financial advice."

"I don't feel it should be the responsibility of the social worker to sort out the financial issues of clients."

The first quotation above supports research by Masemola and Taute (2006) that social workers themselves could benefit from honing their financial management skills and that such skills should be included in the training of social work students. The second quotation could imply that social workers still do not have clarity on their role and place in the South African social development paradigm and that the underlying social development theory of "marrying" (Gray, 2006: 59) social and economic development goals does not figure fully in the respondents' social work practice.

However, upon invitation to respondents to make recommendations on social work intervention in respect of their clients' debt, $62(84 \%)$ of them suggested that financial management skills should be facilitated and/or taught by them to clients. This certainly indicates that social workers feel a need to offer financial literacy education to financially vulnerable households.

\section{CONCLUSIONS AND RECOMMENDATIONS}

The findings of this research study clearly indicate that economic growth in South Africa cannot be handled on the macro-level only, but should also be managed by means of social welfare assistance on a micro-level. It is therefore imperative that the financial vulnerability of households is addressed by social workers, through social service delivery within the social development paradigm. Currently social workers do focus on the poorest households in South Africa, in accordance with the Integrated Service Delivery Model of the Department of Social Development (2006), but are uncertain about their role in addressing the indebtedness of these households, who present the highest debt levels in the country. Social workers are still caught up in their clients' individual psycho-social problems to the extent that sustained services directed at reducing households' financial vulnerability are neglected. Financial literacy education as a tool for poverty alleviation is thus largely not employed, even though the connection between financial education and poverty alleviation has been scientifically confirmed (Bell \& Lerman, 2005; Jacob et al., 2000; Sandlant et al., 2005). This fact should be viewed against the finding of this research study that more than half the households making up the caseloads of participating social workers are, according to them, financially over-indebted, but fewer than half of the social work respondents are doing anything about it. Social welfare organisations therefore ought to clarify in a concrete manner the role of the social workers whom they employ with respect to their clients' indebtedness.

One of the main reasons for the lack of financial education provided by social workers to vulnerable households seems to relate to their own uncertainty about the nature and scope of this financial education. In addition, social workers are trying, mostly on an individual level and in spite of huge unmanageable caseloads, which often entail dealing with statutory crises, to assist over-indebted households with their budgets. Available resources and services by 
financial institutions (for example, financial literacy programmes), statutory bodies (for example, debt counsellors of the National Credit Regulator) and volunteers in communities are not utilised optimally and facilitation is minimal. This suggests that social workers' and students' notions of financial literacy education ought to be stimulated, so that financial education as part of intervention to vulnerable households could be integrated by them with informed confidence. Methods of financial education should be extended to employ not only casework as a social work method, but should also integrate group and community work. Social workers should become more aware of which resources in the community could contribute to the financial education of households and they should develop ways in which to facilitate them.

Resistance by households to accept intervention in respect of their indebtedness, other than direct material assistance, is also handled with resignation, probably as a result of social workers' ignorance of theories of debt behaviour and on how to integrate these with social work intervention theories. Indebtedness of clients is furthermore largely assessed as survival debt by social workers, which is indirectly dependent on macro-economic variables. The nonhierarchical interplay of cognitive and affective debt, which can be managed on the micro-level through social work service delivery based on social work theories for changed behaviour is thus not realised and/or considered. The myth that lower-income groups cannot or will not save also plays a part in social workers' lack of involvement in debt reduction intervention, because the culture of debt, debt behaviour, and the interwoven nature thereof, disguise the fact that there might be substantial amounts of money in circulation in many financially vulnerable households. This statement is complicated by the context-bound consideration of what is essential for survival by financially vulnerable households. Theories pertaining to the debt behaviour of financially vulnerable households should therefore be developed further within a social work perspective, to be integrated meaningfully with social work theories leading to social change. The dynamics of survival, cognitive and affective debt, as well as the capacity of financially vulnerable households to save, ought also to be explored and accessed multidimensionally within specific contexts to serve as basis for social work intervention.

This research confirms the correlation between financial and human well-being, as well as the role of social workers practising within a social development paradigm on the micro-level towards integrated service delivery, which includes both economic and social development. Therefore, social workers' participation in interdisciplinary education campaigns to promote savings and financial literacy education is of cardinal importance to the profession in order to respond to indebtedness as a phenomenon in communities. This recommendation is based on the finding that social work respondents in this research study expressed the need to become involved in the financial education of vulnerable households in their caseloads. Ultimately this conclusion could act as mandate for social work intervention in respect of financially vulnerable households' over-indebtedness.

The majority of social work clients in South Africa are un-banked and/or under-banked, and are at present insufficiently served by financial institutions. If social workers do not become involved with the indebtedness of financially vulnerable households in their caseloads ... who will?

\section{REFERENCES}

ALIBER, M. 2001. Study of the incidence and nature of chronic poverty and development policy in South Africa: an overview. Chronic poverty and development policy series, no. 1. Cape Town: Programme for Land and Agrarian Studies, University of the Western Cape. 
BELL, E. \& LERMAN, R.I. 2005. Can financial literacy enhance asset building? Washington DC: The Urban Institute.

BLACK SASH, 2000. The lender's slaves: money lending in South Africa. Indicator SA, 17(1):59-64.

BRAUNSTEIN, S. \& WELCH, C. 2002. Financial literacy: An overview of practice, research and policy. Federal Reserve Bulletin, November: 445-457.

BUYS, F. 2008. Suid-Afrika verdien iets beters as blaamkultuur (South Africa deserves something better than a blaming culture). Rapport, 4 Mei.

CILLIE, J. 2008. In skuld gebore, maar so sterf is onnodig (Born in debt, but to die like this is unnecessary). Rapport, 9 Februarie.

COLLINS, D. 2007. Focus note: Styles and profiles, investigating the financial lives of the poor. The connection between livelihoods and financial portfolios of the poor. Available: www.financialdiaries.com. [Accessed: 28/04/2007].

CRESWELL, J.W. 1998. Qualitative inquiry and research design: choosing among five traditions. Thousand Oaks: Sage Publications.

DELPORT, C.S.L. \& FOUCHÉ, C.B. 2005. The qualitative research report. In: DE VOS, A.S. (ed) Research at grass roots. A primer for the caring professions. Pretoria: Van Schaik Publishers.

DEPARTMENT OF SOCIAL DEVELOPMENT, 2006. Integrated service delivery model towards improved social services. RP31. Pretoria: Government Printer.

DU PREEZ, L. \& CLAYTON, C. 2004. You can bank on high costs. Personal Finance, 21 August. Available: http://http.persfin.co.za/index.php?fSetId=300\&fSectionId=592\&fArticleId $=2194760$ [Accessed: 30/06/2008].

DUVENHAGE, H. 2008a. Sweedse navorser weerlê mites oor KMO's (Swedish researcher confutes myths on SMOs). Rapport, 4 Mei.

DUVENHAGE, H. 2008b. As produk reg is, sal hulle spaar (If product is right, they would save). Rapport, 1 Junie.

ENGELBRECHT, L.K. 2008a. Financial literacy education within a developmental social work paradigm. The Social Work Practitioner-Researcher, 20 (1):3-20.

ENGELBRECHT, L.K. 2008b. The scope of financial literacy education: a poverty alleviation tool in social work? Social Work/Maatskaplike Werk, 44(3):252-262

ENGELBRECHT, L.K. 2008c. Economic literacy and the war on poverty: A social work challenge? International Journal of Social Welfare, 17(2):166-173.

EYBERS, J. 2008. Meeste in SA besit hul huis (Most in SA possess their houses). Rapport, 16 Maart.

FAIR SHARE, 2001. How the South African economy works. South African banking systems. University of Western Cape: School of Government.

FINMARK TRUST. 2007. Access to savings products in the low income market. Johannesburg: South Africa Savings Institute. 
FOUCHÉ, C.B. \& DELPORT, C.S.L. 2002. Introduction to the research process. In: DE VOS, A.S. (ed) Research at grass roots. Pretoria: Van Schaik Publishers.

FOYER, M. 2000. Debt and democracy: the freedom to exploit. Report for Black Sash. Unpublished paper.

GELINAS, J.B. 1998. Freedom from debt: The reappropriation of development through financial self-reliance. London \& New York: Zed Books Ltd.

GOODWIN-GROEN, R.P. \& KELLY-LOUW, M. 2006. The National Credit Act and its Regulations in the context of access to finance in South Africa. Marshalltown: FinMark Trust.

GOUS, F. 2008. 6,4 miljoen verbruikers het slegte kredietrekord (6,4 million consumers have a bad credit record). Sake-Rapport, 11 Mei.

GRAY, M. 2006. The progress of social development in South Africa. International Journal of Social Welfare, 15(1):53-64.

GRINNELL, R.M., UNRAU, Y.A. \& WILLIAMS, M. 2005. Scientific inquiry and social work. In GRINNELL, R.M \& UNRAU, Y.A. (eds) Social work research and evaluation. Quantitative and qualitative approaches $\left(7^{\text {th }}\right.$ ed $)$. Oxford: Oxford University Press.

HARE, I. 2004. Defining social work for the $21^{\text {st }}$ century. The International Federation of Social Workers' revised definition of social work. International Social Work, 3(47):406-424.

HARRIS, M. 2008. As SA 'n dorp was... (If SA were a town...). Rapport, 4 Mei.

HUMAN SCIENCES RESEARCH COUNCIL. 2002. Micro-finance in rural communities in Southern Africa. Country and pilot site case studies, policy issues and recommendations. Pretoria: W.K. Kellogg Foundation.

HURWITZ, I. \& LUIZ, J. 2007. Urban working class credit usage and over-indebtedness in South Africa. Journal of Southern African Studies, 33 (1):107-131.

INSOL INTERNATIONAL. 2001. Consumer debt report: Report of findings and recommendations. London: International Federation of Insolvency Professionals.

JACOB, K., HUDSON, S. \& BUSH, M. 2000. Tools for survival: An analysis of financial literacy programs for lower-income families. Chicago: Woodstock Institute.

LOXTON, L. 2004. Inside parliament. Committees jumping into remedial action. Business Report, 11 October.

MANUEL. T 2004. Address to South African Savings Institute. Metropolitan excellence research awards. Reserve Bank Conference Centre, 18 October.

MARSHALL, C. \& ROSSMAN, G.B. 1999. Designing qualitative research $\left(3^{\text {rd }}\right.$ ed). London: Sage Publications.

MASEMOLA, M. \& TAUTE, F. 2006. The impact of financial problems on the productivity of employees of the Department of Social Services, Population and Development, Ermelo district. The Social Work Practitioner-Researcher, 8(1):39-55.

MASHIGO, P. 2006. The debt spiral in the poor households in South Africa. The International Indigenous Journal of Entrepreneurship, Advancement, Strategy and Education, 1 October. 
MAVRINAC, S. \& PING, C.W. 2004. Financial education of women in Asia Pacific: An INSEAD working paper. Singapore: INSEAD Campus.

MICRO-FINANCE REGULATORY COUNCIL. 1999. Available: http://www.mfrc.co.za/ [Accessed: 30/06/2008].

MICRO-FINANCE REGULATORY COUNCIL. 2003. Submission to the Portfolio Committee on Finance on indebtedness. 17 June.

MITTNER, M. 2008. Bestee jy meer as wat verdien? (Are you spending more what you earn?). Sake24, 23 Februarie.

MULLER, P. 2008. Die kosskaarste kom van ver af (The food scarcity comes from far). Perspektief, 27 April.

NAGDEE, Q. 2004. The debt trap: the indebtedness of the poor in South Africa. Bellville: University of the Western Cape. (Unpublished MA thesis)

NASH, J., JENKINSON, A., VAYRO, A. \& SANDLANT, R. 2005. Understanding personal debt and financial difficulty in Australia. Melbourne: ANZ \& ACNielson.

PATEL, L. 2005. Social welfare and social development in South Africa. Southern Africa: Oxford University Press.

PIPREK, G., DLAMINI, P. \& COETZEE, G. 2004. Financial literacy scoping study and strategy project. Final report. FinMark Trust. ECIAfrica. Consulting Pty Ltd. Available: ftp: ftp.fsb.co.za/public/Consumer\%20Education/FinLit \%20Report.pdf [Accessed: 30/06/2008].

POLLARD, E. \& DAVIDSON, L. 2001. Foundations of child well-being. Paris: UNESCO, Action Research in Family and Early Childhood.

PORTEOUS, D. 2003. The demand for financial services by low income South Africans. Marshalltown: FinMark Trust.

RAND, D. 2004. Financial education and asset building programs for welfare recipients and low income workers: the Illinois experience. Washington DC: The Brookings Institution, Center on Urban and Metropolitan Policy.

RICHMOND, M.E. 1917. Social diagnosis. New York: Russel Sage Foundation.

ROY MORGAN RESEARCH, 2003. ANZ survey of adult financial literacy in Australia. Stage 3 in-depth interview survey report. Melbourne: ANZ Banking Group.

RUTHERFORD, S. 1999. Savings and the poor. The methods, use and impact of savings by the poor of East Africa. Available: www.MicroSave.org [Accessed: 30/06/2008].

RSA (REPUBLIC OF SOUTH AFRICA). 2004. Policy framework for consumer credit. Department of Trade and Industry: Consumer Credit Law Reform, August.

RSA (REPUBLIC OF SOUTH AFRICA). 2005. National Credit Act no. 34 of 2005. Government Gazette, No. 28619 of 15 March 2006, Vol. 489. Pretoria: Government Printers.

RSA (REPUBLIC OF SOUTH AFRICA). 2006. National Credit Regulations. Government Gazette, No. 28864 of 31 May 2006, Vol. 491, Regulation Gazette 8477, R489. Pretoria: Government Printers.

SANDLANT, R., HARRIS, A. \& BARKER, N. 2005. AZN Survey of adult financial literacy in Australia. Melbourne: AZN \& AC Nielson. 
SCHOOMBEE, A. 2000. Banking for the poor: the success and failures of South African banks. Paper presented at the DEVNET conference on "Poverty, prosperity and progress", Victoria University of Wellington, New Zealand, 17-19 November.

SCHUTT, R.K. 2005. Sampling. In GRINNELL, R.M \& UNRAU, Y.A. (eds) Social work research and evaluation. Quantitative and qualitative approaches $\left(7^{\text {th }} \mathrm{ed}\right)$. Oxford: Oxford University Press.

SIEPPERT, J.D., McMURTY, S.L. \& MCCLELLAND, R.W. 2005. In: GRINNELL, R.M. \& UNRAU, Y.A. (eds) Social work research and evaluation. Quantitative and qualitative approaches $\left(7^{\text {th }} \mathrm{ed}\right)$. Oxford: Oxford University Press.

SHERRADEN, M. \& SHERRADEN, M.M. 2004. Household credit and saving performance in Individual Development Accounts. Paper at conference on "Consequences of the consumer lending revolution" at the Center for Social Development, Washington University in St. Louis, St. Louis University, 8-9 December.

STATISTICS SOUTH AFRICA. 2007. A national poverty line for South Africa. Available: http://www.treasury.gov.za/publications/other/povertyline/Treasury\%20StatsSA\%20poverty\%2 0line\%20discussion\%20paper.pdf. [Accessed: 10/04/2009].

THE PRESIDENCY REPUBLIC OF SOUTH AFRICA. 2008. Development Indicators. Available: http://www.southafricahouse.com/2008development.pdf. [Accessed: 30/06/2008].

UECKERMANN, H. 2008. Gaping tussen ryk en arm bly (Gab between rich and poor stays). Rapport, 9 Maart.

VAN ROOYEN, D. 2008a. Nog pogings kom om SA meer te laat spaar (More attempts follow to let SA save more). Sake-Rapport, 20 April.

VAN ROOYEN, D. 2008b. Huismark vir goedkoper eiendom trek ook noustrop (Property market for cheaper property is also under pressure). Rapport, 17 Februarie.

VAN TONDER, J. 2008. Armes se toelaes die rede vir probleme (The grants to the poor are the reason for problems). Rapport, 17 Februarie.

VAN ZYL, A. 2008a. Meer mense in SA het nou ' $n$ bankrekening danksy Mzansi (More people in SA now have a bank account thanks to Mzansi). Sake-Rapport, 16 Maart.

VAN ZYL, A. 2008b. Kundige hulp op pad vir die wat swaar aan skuld dra (Expert help on the way for those indebted). Rapport, 18 Mei.

WATSON, L. 2008. Middelklas en rykes bestee nou die minste (Middle class and the rich spending the least). Rapport, 17 Februarie.

Dr Lambert K Engelbrecht, Senior Lecturer, Department of Social Work, Stellenbosch University, Stellenbosch, South Africa. 